\title{
The Autonomy Rationale for Religious Freedom
}

\author{
Farrah Ahmed*
}

Courts and scholars across jurisdictions increasingly identify personal autonomy as the primary rationale for the right to religious freedom. But there are tensions between autonomy on one hand, and religious belief, practice and proselytism on the other. This paper will focus on two tensions which have unappreciated implications for religious freedom jurisprudence, particularly that of the ECHR. The first tension stems from the resistance of some religious beliefs to revision. The second stems from the manipulative nature of some modes of religious proselytism. This paper argues that, given these tensions, the protection currently offered to religious beliefs, practices and proselytism by the right to religious freedom cannot be justified by reference to the value of autonomy. This finding has significant implications for the justification of the right to religious freedom.

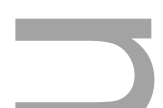

\section{INTRODUCTION}

There is widespread agreement that religious freedom ought to be protected as a legal right. There is much less agreement on why.

Proposed rationales include the value of faith, ${ }^{1}$ the nature of conscience, ${ }^{2}$ the futility of religious coercion and the importance of finding religious truth. ${ }^{3}$ The underlying rationale(s) of the right to religious freedom guide the protection it will offer. For instance, if the maintenance of civil peace were the primary rationale for religious freedom, the right

\footnotetext{
* Associate Professor, Melbourne Law School, University of Melbourne. Reema Muneer introduced me to literature in psychology that shaped this paper in significant ways. Adam Perry, Carolyn Evans, Joel Harrison, Dale Smith, Jarrod Hepburn, Tarun Khaitan, Lulu Weis and Jonathan Crowe generously offered insightful feedback on earlier drafts. I gratefully acknowledge the many helpful comments received at the Legal Theory Workshop and the Constitutional Theory Workshop at Melbourne Law School, the Oxford Public Law Discussion Group and the faculty seminar at the Centre for Transnational Legal Studies. The Law Research Service at Melbourne Law School provided excellent assistance in preparing this manuscript.

${ }^{1}$ T. Macklem, 'Faith as a Secular Value' (2000) 45 McGill Law Journal 1.

${ }^{2}$ M. J. Sandel, 'Religious Liberty_Freedom of Conscience or Freedom of Choice?' [1989] Utah Law Review 597.

${ }^{3}$ J. H. Garvey, ‘An Anti-Liberal Argument for Religious Freedom' (1996) 7 Journal of Contemporary Legal Issues 275. See, generally, R. McCrea, Religion and the Public Order of the European Union (New York: OUP, 2010) 106-115.
}

This is the author manuscript accepted for publication and has undergone full peer review but has not been through the copyediting, typesetting, pagination and proofreading process, which may lead to differences between this version and the Version of Record. Please cite this article as doi: $10.1111 / 1468-2230.12253$.

This article is protected by copyright. All rights reserved. 
might well not protect pacifist minorities whose oppression would not threaten civil peace. ${ }^{4}$ Understanding the rationale(s) for the right to religious freedom is imperative because the protection offered by the right is so deeply contested. Does it protect girls who wear religious dress to school, bakers who refuse to write messages in support of same sex marriage on cakes, parents who support corporal punishment of their children in schools, airline employees who wear visible crosses, members of the armed forces who proselytise to lowerranking officers, and those who detain their family members to undo the influence of a socalled cult? Responding correctly to these kinds of questions requires an understanding of the rationale(s) for the right to religious freedom.

Increasingly, courts and scholars across jurisdictions identify personal autonomy as the primary rationale for the right to religious freedom. ${ }^{5}$ Personal autonomy generally refers to the ideal of controlling, creating, authoring or shaping one's own life. Religion plays an important part in the lives of many; the freedom to make choices on religious matters is thought to enhance personal autonomy overall. The growing significance of autonomy as a rationale for religious freedom is supported by its growing significance for other human rights, ${ }^{6}$ and in theories of constitutional rights more generally. ${ }^{7}$

This paper unsettles the status of autonomy as the primary rationale for religious freedom. It argues that while autonomy is an attractive rationale, it does not count in favour of the full range of protection currently offered by the right in liberal states. This is because

\footnotetext{
${ }^{4}$ Garvey, ibid, 280-281.

${ }^{5}$ See generally, C. Evans, Freedom of Religion under the European Convention on Human Rights (Oxford: OUP, 2001) 29-33; McCrea, n 3 above, 110; K. Greenawalt, Religion and the Constitution vol 1 (Princeton, NJ: Princeton University Press, 2006) 3-4; A. Brownstein, 'Harmonizing the Heavenly and Earthly Spheres: The Fragmentation and Synthesis of Religion, Equality, and Speech in the Constitution' (1990) 51 Ohio State Law Journal 89, 95; B. Berger, 'Law’s Religion: Rendering Culture’ (2007) 45 Osgoode Hall Law Journal 277; D. Laycock, 'Religious Liberty as Liberty' (1996) 7 Journal of Contemporary Legal Issues 313; F. B. Cross, Constitutions and Religious Freedom (New York: CUP, 2015) 32; see the section headed 'Autonomy in Religious Freedom Jurisprudence' below. cf R. Ahdar and I. Leigh, Religious Freedom in the Liberal State (Oxford: OUP, 1sted, 2005) 60-62; Garvey, n 3 above, 278-279; Sandel, n 2 above; A. Koppelman, 'Religious Establishment and Autonomy’ (2008) 25 Constitutional Commentary 291.

${ }^{6}$ Pretty v United Kingdom (2002) EHRR 1 at [61].

${ }^{7}$ K. Möller, 'Two Conceptions of Positive Liberty: Towards an Autonomy-based Theory of Constitutional Rights' (2009) 29 Oxford Journal of Legal Studies 757; Evans, n 5 above, 33. See Jehovah's Witnesses of Moscow v Russia (2011) 53 EHRR 4 at [135]; Pretty v United Kingdom ibid at [61], [65].
}

This article is protected by copyright. All rights reserved. 
there are tensions between autonomy on one hand, and religious belief, practice and proselytism on the other. ${ }^{8}$ This paper will focus on two tensions which have unappreciated implications for religious freedom jurisprudence. The first tension stems from the resistance of some religious beliefs to revision. The second stems from the manipulative nature of some modes of religious proselytism.

This paper finds that as a result of these tensions, the legal protection offered to religious freedom does not always enhance, and may even diminish, autonomy. Therefore autonomy on its own does not support or count in favour of the protection currently offered to religious beliefs, practices and proselytism by the right to religious freedom. In particular, autonomy cannot support the protection currently offered to some religious beliefs which are resistant to revision, and to certain types of manipulative proselytism. This finding suggests that the protections offered by the right to religious freedom are not wholly justified, or that other rationales, alone or in concert with autonomy, underlie the right. The paper makes these findings in the context of the European Convention on Human Rights (ECHR) jurisprudence on freedom of religion. However, they are relevant beyond this context: they bear upon the justificatory role of autonomy in all jurisdictions with similar protections for religious freedom. ${ }^{9}$

In the section that follows, the paper will outline the role that autonomy plays in ECHR jurisprudence. It will then argue that the autonomy rationale cannot support the protection currently offered by the legal right to religious freedom to beliefs that are resistant to revision (in the section headed 'Resistant Beliefs'), as well as the protection offered to manipulative proselytism (under the heading 'Manipulative Proselytism'). The following section will discuss the implications of these findings and the final section will discuss their significance. In making these arguments, the paper draws on legal doctrine and the literature

\footnotetext{
${ }^{8}$ For some of them, see Evans, n 5 above 32; P. G. Danchin, 'Of Prophets and Proselytes: Freedom of Religion and the Conflict of Rights in International Law' (2008) 49 Harvard International Law Journal 249, 277 ; M. W. McConnell, 'God Is Dead and We Have Killed Him!: Freedom of Religion in the Post-modern Age' [1993] Brigham Young University Law Review 163, 173; McCrea, n 3 above, 111-115, 129.

${ }^{9}$ For the relevance of autonomy in Canadian religious freedom jurisprudence, see Berger, n 5 above, 291-300; Syndicat Northcrest v Amselem [2004] 2 SCR 551 at [40], [42]; R v Big M Drug Mart Ltd [1985] 1 SCR 295, 351 (SCC); Zylberberg v Sudbury Board of Education (1988) 65 OR (2d) 641 (On CA). On autonomy in US religious freedom jurisprudence, see Greenawalt, n 5 above, 3-4; L. Tribe, American Constitutional Law (New York: Foundation Press, 3rd ed, 2000) 1284-1300.
}

This article is protected by copyright. All rights reserved. 
on personal autonomy in legal, moral and political philosophy; it also draws on theoretical reviews and empirical studies on beliefs, attitudes and manipulation in psychology.

\section{AUTONOMY IN RELIGIOUS FREEDOM JURISPRUDENCE}

Personal autonomy is the ideal of controlling, creating, authoring or shaping your own life. ${ }^{10}$ While there are disagreements about the nature of personal autonomy in legal and political philosophy, the relevant legal doctrine and the scholarship largely share a core conception of the ideal. ${ }^{11}$ This shared conception of autonomy may however be expressed in different forms: as the ideal of 'self-definition', 12 'self-determination', 13 'controlling', 'governing', 'fashioning', 'making' or 'authoring' your own life. ${ }^{14}$ Scholarship on autonomy in religious freedom jurisprudence is strongly influenced by the work of Joseph $\operatorname{Raz}^{15}$ partly because he appeals to this core, shared conception of autonomy. ${ }^{16}$ Beyond this shared conception of autonomy, this paper will defend positions on particular debates on the nature of autonomy when required.

Personal autonomy can only be achieved under certain conditions. There is widespread agreement amongst legal scholars (often implicitly shared by courts) that these conditions include a degree of freedom from coercion and manipulation, and possession of an

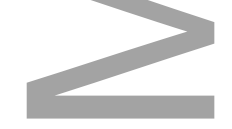

${ }^{10}$ J. Raz, The Morality of Freedom (Oxford: Clarendon Press, 1986) 369.

${ }^{11}$ S. Buss, 'Personal Autonomy' in E. N. Zalta (ed), The Stanford Encyclopedia of Philosophy (2002) http://plato.stanford.edu/entries/personal-autonomy/ (last accessed 28 May 2013) notes the overlaps between prominent accounts of autonomy.

${ }^{12}$ Syndicat Northcrest $\mathrm{v}$ Amselem $\mathrm{n} 9$ above at [42].

${ }^{13}$ Ahdar and Leigh, n 5 above, 58; M. S. McDougal, H. D. Lasswell and L. Chen, 'The Right to Religious Freedom and World Public Order: The Emerging Norm of Nondiscrimination' (1975) 74 Michigan Law Review 865, 873; Brownstein, $\mathrm{n} 5$ above, 95.

${ }^{14}$ Evans, n 5 above 29; Raz, n 10 above, 369; see also S. D. Smith, 'Believing Persons, Personal Believings: The Neglected Center of the First Amendment' [2002] University of Illinois Law Review 1233, 1248-1249; A. R. Mele, Autonomous Agents: From Self-Control to Autonomy (Oxford: OUP, 1995) 8.

${ }^{15}$ See, eg, Evans, ibid, 29; M. Kiviorg, 'Religious Autonomy in the ECHR' (2009) IV Derecho y Religión 131; Koppelman, $\mathrm{n} 5$ above, 293.

${ }^{16}$ D. McCabe, 'Joseph Raz and the Contextual Argument for Liberal Perfectionism' (2001) 111 Ethics 493, 494-495. 
adequate range of options. ${ }^{17}$ Certain capacities, including mental capacities of reasoning and rationality, as well as psychological characteristics like self-control, are also necessary for autonomy. ${ }^{18}$ No-one can control or create every aspect of their life. Biological parents, for instance, are not chosen. So autonomy is a matter of degree, and even the most thoroughly autonomous life will be only partly shaped by the person leading it. ${ }^{19}$

Autonomy can be used in a 'local' as well as 'global' sense. The global sense is the one we appealed to earlier: autonomy as the ideal of living a life you control, create or shape. But judgements of autonomy can be made with respect to a single action, belief or desire. ${ }^{20}$ These judgements are not always easy to make and will be explored further later in this paper.

It may seem that as long as an agent is uncoerced and not manipulated, her action is autonomous. But when an unwilling addict injects herself with heroin, many are disinclined to count her action as autonomous, even if noone coerces or manipulates her. ${ }^{21}$ It seems as though injecting heroin is not what she truly wants. ${ }^{22}$ Cases like this bring to the fore another pre-condition for autonomous action: that we identify with the beliefs or desires we act upon. The precondition of 'identification' has been described as 'the most important metaphor in the literature on autonomy'. ${ }^{23}$ Identification entails endorsing a belief or desire and accepting it as part of oneself. ${ }^{24}$ Identification is contrasted with alienation, the condition of repudiating a belief or desire, and rejecting it as part of oneself. ${ }^{25}$ Alienation stands in the way of autonomy because when a person is 'driven by forces which he disowns but cannot control' and 'hates or detests the desires which motivate him or the aims that he is pursuing', he does

\footnotetext{
${ }^{17}$ Raz, n 10 above, 373-376; Koppelman, n 5 above, 293; Evans, n 5 above 29; Greenawalt, n 5 above, 9; Kiviorg, n 15 above, 140.

${ }^{18}$ Mele, n 14 above, 112-126; Raz, ibid, 384.

${ }^{19}$ Raz, ibid, 204.

${ }^{20}$ Mele, n 14 above, 149.

${ }^{21}$ R. Moran in S. Buss and L. Overton, Contours of Agency: Essays on Themes from Harry Frankfurt (Cambridge, Mass: MIT Press, 2002) 192.

${ }^{22}$ H. Frankfurt, The Importance of What We Care About (Cambridge: CUP, 2006) 164.

${ }^{23}$ Buss, n 11 above.

${ }^{24}$ Moran, Buss and Overton, n 21 above, 191.

${ }^{25}$ J. Christman, 'Liberalism, Autonomy, and Self-Transformation' (2001) 27 Social Theory and Practice 185, 202; see also Raz, n 10 above, 382.
}

This article is protected by copyright. All rights reserved. 
not act autonomously. ${ }^{26}$ Such an agent is ruled by his beliefs and desires; he does not rule himself. Identification is also contrasted with ambivalence, the condition of neither endorsing nor repudiating, and neither accepting nor rejecting, a belief or desire. ${ }^{27}$ As will be discussed later in this paper, it is widely accepted that ambivalence is antithetical to autonomy. ${ }^{28}$

Judgments of autonomy or lack of it can be made with respect to particular domains of a person's life. So a person who is coerced and manipulated in her family life (and is therefore non-autonomous in this sphere) might still be autonomous in her professional life. ${ }^{29}$ For many people, the preconditions of autonomy - including an adequate range of options and the absence of coercion and manipulation - are of particular salience in certain domains of life: eg, intimate or family life, decisions about the body or political activity. ${ }^{30}$ Personal autonomy is an attractive rationale for the right to religious freedom because religious life is thought to be one such domain. ${ }^{31}$ As one scholar puts it:

[t] he fullest personal autonomy will exist in a society in which a person sees the availability of a range of good choices in regard to religion or belief and is able to make meaningful decisions about which, if any, of these choices he or she wishes to adopt. ${ }^{32}$

The jurisprudence of the European Court of Human Rights (ECtHR) reflects the autonomy rationale for religious freedom. In Jehovah's Witnesses of Moscow v Russia, the Court in a unanimous judgment appealed to autonomy as a rationale for religious freedom by casting religious freedom as 'the individual's right to personal autonomy in the sphere of ... religious beliefs ${ }^{33}$ and by emphasising that the state 'must advance serious and compelling reasons for an interference with the choices that people may make in pursuance of the religious standard of behaviour within the sphere of their personal autonomy. ${ }^{34}$ In probably the most influential

26 Raz, ibid, 382; Buss, n 11 above; L. Ekstorm, 'Alienation, Autonomy, and the Self' (2005) 29 Midwest Studies in Philosophy 45, 47.

${ }^{27}$ Frankfurt, n 22 above, 165.

${ }^{28}$ E. Barvosa- Carter, 'Mestiza Autonomy as Relational Autonomy: Ambivalence and the Social Character of Free Will (2007) 15 Journal of Political Philosophy 1, 4.

${ }^{29}$ Mele, n 14 above, 8 .

${ }^{30}$ Möller, $\mathrm{n} 7$ above, 771 .

31 ibid, 779.

${ }^{32}$ Evans, n 5 above 30.

${ }^{33}$ Jehovah's Witnesses of Moscow v Russia $\mathrm{n} 7$ above at [134].

${ }^{34}$ ibid at [119] (emphasis added); see also at [142].

This article is protected by copyright. All rights reserved. 
ECHR case on religious freedom, Kokkinakkis v Greece $^{35}$ (Kokkinakkis), the majority’s description of religious freedom as 'one of the most vital elements that go to make up the identity of believers and their conception of life', 'repeated talismanically in all the later cases', ${ }^{37}$ has also been taken to reflect the autonomy rationale. ${ }^{38}$ The case's approach to proselytism has been explained by reference to autonomy: the court is said to have recognised a right not to be 'subject to autonomy infringing persuasion techniques, ${ }^{, 39}$ and 'autonomy reducing conversion techniques'. ${ }^{40}$ Judge Martens based his (partly dissenting) decision on the principle that 'everybody is capable of determining his fate in the way that he deems best'. ${ }^{41}$ Judge Tulkens in another influential ECHR case, Sahin v Turkey, noted the relevance of the 'real right to personal autonomy' developed by the court to religious freedom. ${ }^{42}$

Autonomy also appears to underpin particular facets of the legal right to religious freedom. The jurisprudence on the freedom to change religion, ${ }^{43}$ the jurisprudence on religious freedom of people seeking or refusing medical treatment, ${ }^{44}$ and the state's 'positive obligation to ensure the peaceful enjoyment of the rights' guaranteed by Article 9 of the ECHR $^{45}$ are plausibly characterised by prominent commentators as reflecting the autonomy rationale.

The jurisprudence of UK courts on ECHR religious freedom protections increasingly reflects this view of autonomy as the rationale for religious freedom. In Williamson, ${ }^{46}$ Lord Nicholls (with whom three of the four other judges agreed) endorsed the Canadian Supreme

\footnotetext{
${ }^{35}$ Kokkinakis v Greece (1994) 17 EHRR 397.

${ }^{36}$ ibid at [31]

${ }^{37}$ Evans, n 5 above 201.

${ }^{38}$ Möller, $\mathrm{n} 7$ above.

${ }^{39}$ P. W. Edge, Religion and Law (Aldershot: Ashgate, 2006) 54.

${ }^{40}$ P. W. Edge, 'Religious Rights and Choice under the European Convention on Human Rights' [2000] Web Journal of Current Legal Issues 3; see also Edge, Religion and Law ibid 92.

${ }^{41}$ Kokkinakis n 35 above at [15] (emphasis added).

${ }^{42}$ Sahin v Turkey (2005) 44 EHRR 99 at [12] (dissenting, but making a general point).

${ }^{43}$ See Evans, $n 5$ above 97.

${ }^{44}$ Ahdar and Leigh, n 5 above 30.

${ }^{45}$ R. Clayton and H. Tomlinson, The Law of Human Rights (Oxford: OUP, 2nd ed, 2009) 1327-1328; Kiviorg, $\mathrm{n}$ 15 above, 143 .

${ }^{46} R$ (Williamson) v Secretary of State for Education and Employment [2005] 2 AC 246.
} 
Court's explicitly autonomy-based approach in Syndicat Northcrest v Amselem $^{47}$ where religious freedom was said to 'revolve[] around ... individual autonomy'; ${ }^{48}$ be 'integrally linked with an individual's self-definition ... and ... a function of personal autonomy'; and where personal autonomy was said to 'undergird the right' [to religious freedom]. ${ }^{49}$ In $R$ (Begum) v Headteacher and Governors of Denbigh High School, ${ }^{50}$ Baroness Hale's judgment was premised on autonomy being the primary rationale for religious freedom. She characterised the religious choices of adults as 'the product of a fully developed individual autonomy'. ${ }^{51}$ She endorsed writers' accounts of Muslim religious dress as 'a [woman's] way of regaining control over her body ${ }^{, 52}$ and 'a highly complex autonomous act'. 53

Besides the growing significance of autonomy in the jurisprudence on religious freedom, influential commentators argue that autonomy should be accepted by courts as the primary rationale for religious freedom. ${ }^{54}$ One scholar of Article 9 of the ECHR concludes:

[t] he argument from autonomy seems to be the best approach for the Court to take to interpreting Article 9. It is broadly consistent with the ideas of pluralism, tolerance, and the importance of religion to believers that the Court has already adopted... [I]t acknowledges the importance of religion and belief to the individual and the danger of trivializing that importance by unwarranted or unjustified State interference. This approach emphasizes the dignity of all human beings and the importance of allowing them to make and live out decisions about the issues that are most important to them. ${ }^{55}$

This view is particularly attractive in the ECHR context where other rights protected by the ECHR have been justified by reference to autonomy as well. ${ }^{56}$ Accepting autonomy as the of Europe' in T. Lindholm, W. C. Durham Jr and B. G. Tahzib-Lie (eds), Facilitating Freedom of Religion or Belief: A Deskbook (Leiden: Martinus Nijhoff, 2004) 234-235. See also Kiviorg, n 15 above, 132.

${ }^{55}$ Evans, n 5 above 33 (citations omitted).

${ }^{56}$ Möller, n 7 above; Evans, n 5 above 33; Pretty v United Kingdom n 6 above at [61].
} 
rationale for religious freedom would therefore, it is argued, promote a harmonious and integrated interpretation of the ECHR as a whole. ${ }^{57}$

But the autonomy rationale has also been criticised. It is criticised for not recognising the special or distinctive features of religion, compared to other beliefs or practices (eg, political ones) that are important for autonomy; this failure, it is said, leads to a further failure to single out religion as worthy of special protection. ${ }^{58}$ The autonomy rationale is also criticised for its incongruity with religious views of religious lives as shaped by religious authority, rather than individual choices. ${ }^{59}$ The autonomy rationale is also said to sit uneasily with the communal and social aspects of religions. ${ }^{60}$

These criticisms will not dent the appeal of autonomy for many. They may be happy to accept that there is no reason to offer special protection to religious, as compared to other, beliefs or practices important for autonomy. ${ }^{61}$ They may argue that particular religious descriptions of religious ways of life as non-autonomous do not, without more, upset the autonomy rationale. ${ }^{62}$ They may argue that the communal and social aspects of religions do not, correctly understood, sit uneasily with autonomy; they could in fact enhance autonomy. ${ }^{63}$

The rest of this paper will argue that, regardless of the position taken on these difficult and contentious issues, the juxtaposition of autonomy with religious freedom jurisprudence demonstrates that the autonomy rationale does not support the protection currently offered to religious beliefs, practices and proselytism by the right to religious freedom. The next section

${ }^{57}$ Evans, $n 5$ above 33 .

${ }^{58}$ Ahdar and Leigh, n 5 above 60.

${ }^{59}$ Garvey, $\mathrm{n} 3$ above, 278-279.

${ }^{60}$ McCrea, $\mathrm{n} 3$ above $111-115$.

${ }^{61}$ See B. Leiter, 'Why Tolerate Religion?' (2008) 25 Constitutional Commentary 1.

${ }^{62}$ See for other doubts about this criticism of the autonomy rationale: A. E. Brownstein, 'Right Not to be John Garvey' (1998) 83 Cornell Law Review 767, 789.

${ }^{63}$ F. Ahmed, Religious Freedom Under the Personal Law System (Oxford: OUP, 2016) 61, 73; see A. Margalit and J. Raz, 'National Self-Determination' (1990) 87 The Journal of Philosophy 439, 448; W. Kymlicka, Liberalism, Community, and Culture (Oxford: Clarendon Press, 1989) 162-182; J. Raz, Ethics in the Public Domain: Essays in the Morality of Law and Politics (Oxford: Clarendon Press, 1994) 177; D. Réaume, 'Justice Between Cultures: Autonomy and the Protection of Cultural Affiliation' (1995) 29 University of British Columbia Law Review 117, 121-135.

This article is protected by copyright. All rights reserved. 
will demonstrate, in particular, that autonomy does not support the protection offered to religious beliefs that are resistant to revision.

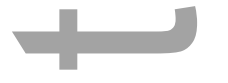

\section{RESISTANT BELIEFS}

Religious freedom jurisprudence recognises that religious beliefs can change. Lord Nicholls in Williamson notes that an individual's beliefs are not 'fixed and static' and that that they 'are prone to change over his lifetime. ${ }^{64}$ The Canadian case, Syndicat Northcrest v Amselem, relied on in UK courts, also takes religious belief to be 'vacillating' and changeable, observing that, '[o]ver the course of a lifetime, individuals change and so can their beliefs. ${ }^{65}$ The freedom to change religious beliefs, which is protected under the ECHR, ${ }^{66}$ presupposes that these beliefs can be changed or revised: there would be no point in protecting the freedom to do what we lack the capacity to do. ${ }^{67}$ These views about the changeability of religious beliefs accord with the fact that people sometimes convert, or change their religious affiliation. ${ }^{68}$ At the same time, many scholarly discussions assume that religious beliefs are very difficult to revise. ${ }^{69}$ ('Revision', as used here, excludes change where existing beliefs are merely strengthened.) Religious freedom scholarship which casts religious beliefs as nonvoluntary, ${ }^{70}$ a species of insanity ${ }^{71}$ or akin to a disability ${ }^{72}$ appeals to its resistance to revision.

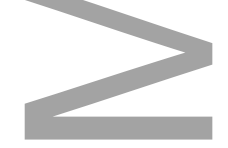

\footnotetext{
${ }^{64} R$ (Williamson) v Secretary of State for Education and Employment $\mathrm{n} 46$ above at [23].

${ }^{65}$ Syndicat Northcrest v Amselem $\mathrm{n} 9$ above at [53].

${ }^{66}$ ECHR, Art 9; Evans, n 5 above 97.

${ }^{67}$ See W. Kymlicka, Multicultural Citizenship: A Liberal Theory of Minority Rights (Oxford: Clarendon Press,
} 1995) 82 .

${ }^{68}$ Pew Research Center on Religion \& Public Life, 'Faith in Flux' (2009) at www.pewforum.org/Faith-inFlux.aspx (last accessed 29 May 2013); R. Barro, J. Hwang and R. McCleary, 'Religious Conversion in 40 Countries’' (2010) 49 Journal for the Scientific Study of Religion 15.

${ }^{69}$ Mele, n 14 above, 153-154; T. H. McLaughlin, 'Parental Rights and the Religious Upbringing of Children' (1984) 18 Journal of Philosophy of Education 75; E. Callan, 'McLaughlin on Parental Rights' (1985) 19 Journal of Philosophy of Education 1; P. Gardner, 'Religious Upbringing and the Liberal Ideal of Religious Autonomy' (1988) 22 Journal of Philosophy of Education 89; J. Morgan, 'Religious Upbringing, Religious Diversity and the Child's Right to an Open Future' (2005) 24 Studies in Philosophy and Education 367.

${ }^{70}$ Sandel, n 2 above, 612-614.

${ }^{71}$ J. H. Garvey, 'Free Exercise and the Values of Religious Liberty' (1986) 18 Connecticut Law Review 779, 798-799. 
The communitarian thesis that we cannot 'stand apart from' or revise those of our religious attitudes that define our sense of personal identity is well known. ${ }^{73}$ This view resonates with the ECtHR's recognition, in a passage endorsed in a number of cases, of religious belief as 'one of the most vital elements that go to make up the identity of believers'. ${ }^{74}$ Some scholarship also suggests that religious freedom should be protected precisely because religious beliefs are resistant to revision. ${ }^{75}$ Thus there are conflicting judicial and scholarly views about the revisability of religious beliefs. Moreover, these views are often assumed, rather than supported with evidence.

Given the uncertainty that surrounds the revisability of religious beliefs, psychological studies on the question are of assistance. They support the view that religious beliefs are at least sometimes resistant to revision. ${ }^{76}$ Seminal studies suggest that where some religious beliefs are involved, there is a resistance towards changing beliefs, even when faced with discrediting information. One case study gives an account of doomsday groups which predicted an apocalyptic event on a particular day. When the day came, and apocalyptic event did not come to pass, the groups maintained and strengthened their religious beliefs instead of abandoning them. The disconfirmation of their prediction was reinterpreted to support their

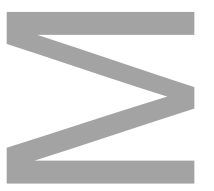

${ }^{72}$ C. L. Eisgruber and L. G. Sager, 'The Vulnerability of Conscience: The Constitutional Basis for Protecting Religious Conduct' (1994) 61 University of Chicago Law Review 1245, 1267 and 1298; M. W. McConnell, 'Religious Freedom at a Crossroads' (1992) 59 University of Chicago Law Review 115, 125.

${ }^{73}$ M. Sandel, Liberalism and the Limits of Justice (New York: CUP, 1982) 150-165.

${ }^{74}$ Kokkinakis n 35 above at [31] (emphasis added).

${ }^{75}$ See, eg, Sandel, $\mathrm{n} 2$ above.

${ }^{76}$ This is not necessarily a quality peculiar to religious beliefs, see, J. Cook, 'The Science for Climate Change Only Feeds the Denial: How Do You Beat That?' The Conversation, 27 January 2016 at https://theconversation.com/the-science-for-climate-change-only-feeds-the-denial-how-do-you-beat-that-52813 (last accessed 7 April 2016); J. Cook and S. Lewandowsky, 'Rational Irrationality: Modelling Climate Change Belief Polarization Using Bayesian atworks http://skepticalscience.com/docs/Cook_2016_rational_irrationality.pdf (last accessed 7 April 2016); P. G. Devine, 'Stereotypes and Prejudice: Their Automatic and Controlled Components' (1989) 56 Journal of Personality and Social Psychology 5, 7, 15; C. D. Batson, 'Rational Processing or Rationalization?: The Effect of Disconfirming Information on a Stated Religious Belief' (1975) 32 Journal of Personality and Social Psychology 176.

This article is protected by copyright. All rights reserved. 
beliefs. ${ }^{77}$ A quasi-experimental study, attempting to explore these findings further, grouped participants on the basis of whether or not they publicly committed to core religious beliefs before presenting them with evidence which discredited these beliefs. The group which had publicly committed to the belief and additionally accepted the discrediting evidence as true reported stronger levels of belief. ${ }^{78}$ (Participants who did not initially commit to the beliefs reported an even lower level of conviction.) Yet another study which focussed on epistemic beliefs, ie, beliefs about the nature of truth and knowledge, found that participants who 'turned to a higher power to resolve their epistemic doubt strengthened old beliefs rather than develop[ing] new ones'. ${ }^{79}$ Naturally, each of these studies has limitations. ${ }^{80}$ But when considered along with the wider supporting literature on cognitive dissonance, which has withstood criticism from competing theorists for decades, ${ }^{81}$ these studies provide evidence of the resistance of some religious beliefs to revision.

These studies are supported by commonly observed features of religious beliefs. Religious beliefs are commonly acquired through early socialisation and habitual practice; beliefs acquired in this way are often difficult to revise. ${ }^{82}$ Religious beliefs are also commonly reinforced by attitudes (ie, evaluations of particular persons, groups, ideas, objects etc) ${ }^{83}$ which make them resiliant. ${ }^{84}$ For instance, a religious belief about the wrongness of consuming beef, supported by a strong aversion to beef-eating inculcated in childhood, is likely to be quite resistant to revision. Finally, it has been argued that familial emotional

\footnotetext{
${ }^{77}$ L. Festinger, H. Riecken and S. Schachter, When Prophecy Fails (Minneapolis: University of Minnesota Press, 1956); J. A. Hardyck and M. Braden, 'Prophecy Fails Again: A Report of a Failure to Replicate' (1962) 65 Journal of Abnormal and Social Psychology 136. For limitations of these studies, see Batson, ibid, 178.

${ }^{78}$ See Batson, ibid, 182.

${ }^{79}$ L. Bendixen, 'A Process Model of Epistemic Belief Change' in B. K. Hofer and P. R. Pintrich (eds), Personal Epistemology: The Psychology of Beliefs About Knowledge and Knowing (New Jersey and London: Laurence Erlbaum, 2002) 201.

${ }^{80}$ See for example Batson, n 76 above, 178.

81 ibid, 176-179.

${ }^{82}$ T. D. Wilson, S. Lindsey and T. Y. Schooler, 'A Model of Dual Attitudes' (2000) 107 Psychological Review 101, 120-121; Devine, n 76 above, 7, 15.

${ }^{83}$ A. H. Eagly and S. Chaiken, 'Attitude Structure and Function' in D. Gilbert, S. Fiske and G. Lindzey (eds), The Handbook of Social Psychology vol 1 (New York: McGraw-Hill, 4th ed, 1998).

${ }^{84}$ Wilson, Lindsey and Schooler, n 82 above, 120-121; Devine, n 76 above, 5, 7, 15.
}

This article is protected by copyright. All rights reserved. 
attachments, cultural identity and deeply-held moral commitments are difficult to revise; ${ }^{85}$ given that many religious beliefs are closely intertwined with these ${ }^{86}$ it is perhaps not implausible then that at least some religious beliefs are also difficult to revise. In what follows, those beliefs which are highly resistant to revision will be described simply as 'resistant'. To be clear, not all religious beliefs are resistant in this sense.

Religious freedom jurisprudence does not currently make a distinction between resistant and non-resistant beliefs in protecting beliefs, and practices based on them. But the resistance of some religious beliefs is clearly relevant to whether autonomy counts in favour of their protection. This section offers three arguments for why autonomy does not generally favour the protection of resistant religious beliefs.

First, when someone holds a resistant belief, it often hinders her from shaping her life based on beliefs and desires with which she identifies. To put it differently, it often hinders her from doing what she truly wants to do. While resistant beliefs tend to stay static, other beliefs change. Desires similarly change over time. As we go through life, not only do our beliefs and desires change, but the beliefs and desires that we identify with, ie that we endorse and accept, change as well. For many, the starkest changes may come with exposure to new stimuli through, eg, going to university, starting at a new school, moving to a new country, starting a new job, travelling, interacting with people from a very different culture, meeting a neighbour with a new political view, reading a book that challenges one's current ideas, experiencing life-altering trauma, losing a loved one. As this list should indicate, stimuli for change are part of the lives of most, if not all, people.

Against this background of change to beliefs and desires, we have resistant religious beliefs which, of course, resist change. We know from psychological studies that it is not unusual for people to retain older resistant beliefs while developing discordant new beliefs and desires. The new beliefs and desires then co-exist with, rather than replace, the older resistant beliefs. ${ }^{87}$ Holding resistant beliefs thus often leads individuals to hold discordant sets of beliefs and desires. Under these circumstances, it is harder for them to act on beliefs and desires with which they identify. That is, it is harder for them to act autonomously. The

\footnotetext{
${ }^{85}$ Christman, n 25 above, 190-193.

86 ibid, 200.

${ }^{87}$ Wilson, Lindsey and Schooler, n 82 above.
} 
following examples will illustrate how resistant beliefs can thwart autonomy by hindering agents from acting on beliefs and desires with which they identify.

\section{Example 1}

Sal is a climate change activist. Over time, Sal has developed strong concerns about climate change. Climate change activism pervades her most fundamental desires and beliefs. Sal strongly identifies with these desires and beliefs. At the same time, Sal also has resistant religious beliefs inculcated in childhood, that require her to perform certain actions on pain of divine punishment. In particular, she believes she must frequently: travel to a distant country on pilgrimage, eat ritually-slaughtered meat, burn incense and drive to a distant place of worship. Assume that these actions all have detrimental implications for climate change. Since they are resistant, these beliefs do not change despite their tension with the central place of climate change activism in Sal's life. While aware of the tension, most of the time she avoids thinking about it altogether. In the rare moments when she does reflect on the tension, she acknowledges to herself that her religious practices are problematic (by the lights of the climate change desires and beliefs with which she identifies). Yet she continues to engage in the religious practices. ${ }^{88}$

In this case, the resistance of Sal's religious beliefs reduces her autonomy, her ability to shape her life. The resistance of her religious beliefs stands in the way of her adopting the climate-friendly lifestyle which she desires, and with which she identifies. While acting on her religious beliefs, she is alienated from them. Ultimately, the resistance of her beliefs has a significant and far-reaching effect on her autonomy. The protection of such beliefs from state interference would not enhance her autonomy.

\section{Example 2}

Mal is a 'family man'. He strongly identifies with beliefs about the importance of maintaining family ties. Mal has a resistant religious belief, inculcated in childhood, that people of his race should only marry within his race, because of their inherent superiority. ${ }^{89}$

\footnotetext{
${ }^{88}$ See further, ibid, for similar scenarios.

${ }^{89}$ See, for a meta-analysis of relations between religiosity and racism, D. L. Hall, D. C. Matz, and W. Wood, 'Why Don't We Practice What We Preach?: A Meta-analytic Review of Religious Racism' (2010) 14 Personality and Social Psychology Review 126.
} 
Intimately associated with this belief ${ }^{90}$ are particular implicit attitudes, ie, "positive and negative evaluations that occur outside of our conscious awareness and control'. ${ }^{91}$ These include implicit attitudes of racial hatred, prejudice and an 'us' versus 'them' mentality. ${ }^{92}$ When his son makes plans to marry a person of a different race, Mal decides to be affectionate to his future daughter-in-law, because of his beliefs about the importance of preserving good familial relationships. Moreover his religious belief does not strictly require him to be rude to people of other races. Despite this decision, Mal finds that he is unable to feel or even act warmly towards his daughter-in-law. Even though he attempts warmth, his behaviour to his daughter-in-law is frequently hostile and rude, and he cannot help but make subtle insinuations about his daughter-in-law's inferiority at every opportunity. ${ }^{93}$ While Mal's religious belief does not strictly require him to act in this way, the implicit racist attitudes associated with his belief make it difficult for him to act otherwise. ${ }^{94}$ The difficulty of changing the implicit attitudes ${ }^{95}$ associated with Mal's religious belief stands in the way of his attempt to shape his family life along the affectionate lines he envisages. ${ }^{96}$

Mal's case is an illustration of how the influence of a resistant religious belief can extend beyond the particular proposition (eg, that people of a race should not marry outside that race) that is believed to be true. Since attitude change is often associated with belief

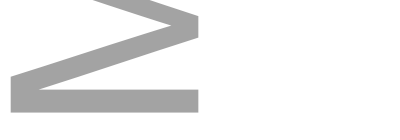

\footnotetext{
${ }^{90}$ Implicit attitudes and beliefs are often associated: O. Gureje, B. O. Olley, E. Olusola and L. Kola, 'Do Beliefs About Causation Influence Attitudes to Mental Illness?' (2006) 5 World Psychology 104; B. A. Nosek, M. R. Banaji and A. G. Greenwald, 'Harvesting Implicit Group Attitudes and Beliefs From a Demonstration Web Site' (2002) 6 Group Dynamics: Theory, Research and Practice 101, 112.

${ }^{91}$ Project Implicit, 'Frequently Asked Questions' at https://implicit.harvard.edu/implicit/faqs.html (last accessed 7 April 2016); M. R. Banaji, 'Implicit Attitudes Can Be Measured' in H. L. Roediger III, I. N. Nairne and A. M. Suprenant (eds), The Nature of Remembering: Essays in Honour of Robert G. Crowder (Washington: American Psychological Association, 2001).

92 ibid.

${ }^{93}$ See Wilson, Lindsey and Schooler, n 82 above, 102, 112.

94 ibid, 104.

${ }^{95}$ N. Dasgupta, 'Implicit Attitudes and Beliefs Adapt to Situations: A Decade of Research on the Malleability of Implicit Prejudice, Stereotypes, and the Self-concept' (2013) 47 Advances in Experimental Psychology 233; N. Dasgupta and S. Asgari, 'Seeing is Believing: Exposure to Counterstereotypic Women Leaders and its Effect on the Malleability of Automatic Gender Stereotyping' (2004) 40 Journal of Experimental Psychology 642.

${ }^{96} \mathrm{See}$, for an explanation of these processes, Devine, n 76 above, 5, 15.
}

This article is protected by copyright. All rights reserved. 
change ${ }^{97}$ resistant religious beliefs can impede autonomy by making attitude change more difficult. This in turn hinders people like Mal from acting on beliefs that they identify with, eg, that family relationships must be preserved. It is worth noting here that this is so even though there is strictly speaking no conflict between Mal's resistant religious beliefs and his family-oriented beliefs. Thus, holding resistant religious beliefs can impede autonomy even when the resistant beliefs do not strictly and directly conflict with a belief with which a person has identified.

These examples of how resistant religious beliefs impede autonomy can be multiplied: cases where religious beliefs hinder acting on sexual beliefs and desires with which a person identifies, eg those associated with LGBTQI identities, are particularly welldocumented. ${ }^{98}$ In such cases, the resistance of religious beliefs stands in the way of sexual autonomy. Protecting these beliefs does not enhance autonomy; autonomy does not count in favour of their protection.

In the examples so far, the agents identify with a belief or desire, but the resistant religious belief hinders them from acting on it. But there is a second, and alternative, way in which resistant beliefs can hinder autonomous action: by encouraging ambivalence. Many scholars of autonomy regard ambivalent action as not truly autonomous because when we are ambivalent

...we are to some degree passive with respect to the action we perform. For in virtue of the fact that we do not unequivocally endorse or support our own motive, it can be appropriately said that what we want ... is in a certain ordinary sense not something we really want. So while it may be that we perform our action on account of the motivating force of our own desire, it is nonetheless also true that we are moved to act by something other than what we really want. ${ }^{99}$

Ambivalence, particularly in actions of great significance to a person, is antithethical to an autonomous life. Contrast the state of ambivalence with an oft-used metaphor (in the literature on autonomy) of the helmsman. The ambivalent person drifts along the waves and

\footnotetext{
${ }^{97}$ For example, through exposure to counterexamples: Dasgupta, n 95 above; Dasgupta and Asgari, n 95 above.

${ }^{98}$ See, D. C. Haldeman, 'When Sexual and Religious Orientation Collide: Considerations in Working With Conflicted Same-Sex Attracted Male Clients’ (2004) 32 The Counseling Psychologist 691, 693; K. A. Mahaffy, 'Cognitive Dissonance and its Resolution: A Study of Lesbian Christians' (1996) 35 Journal for the Scientific Study of Religion 392, 394.

${ }^{99}$ Frankfurt, n 22 above, 163-164.
}

This article is protected by copyright. All rights reserved. 
currents of life, in contrast to the helmsman who steers her course by the light of the beliefs and desires with which she identifies. ${ }^{100}$

A person holding resistant beliefs (it was argued earlier) often holds competing and discordant beliefs as well. There is evidence that this engenders ambivalence. ${ }^{101}$ A person with discordant sets of beliefs is pulled in two directions at once. ${ }^{102}$ This may lead to her to fail to identify with either of the discordant beliefs, or it may lead her to identify with both beliefs, despite their discordance. Some describe the person in the latter scenario as lacking wholeheartedness. ${ }^{103}$ In either scenario, the result is autonomy-diminishing ambivalence.

The resistant beliefs of Sal, Mal and the LGBTQI persons discussed earlier hindered them from acting on beliefs and desires that they identified with. But we can imagine alternative versions of events where the people in these examples respond to their situation with ambivalence. Take Cal, who is similar to Sal in all respects, except that she responds to the discordance between her beliefs and desires relating to religion and climate change by failing to identify with either; if $\mathrm{Cal}$ acts on her religious beliefs, she acts ambivalently.

Similarly, we can imagine LGBTQI people who act ambivalently on their religious beliefs, because of the discordance between their religious beliefs and sexual desires. In such cases, ambivalence in actions of great significance in their lives diminishes their autonomy. Protecting ambivalence-inducing resistant religious beliefs will not enhance autonomy. Autonomy does not therefore count in favour of their protection.

There is a third consideration that suggests that autonomy does not generally favour the protection of resistant religious beliefs: while resistant beliefs are highly resistant to revision, autonomy requires that we have the ability to revise our beliefs. ${ }^{104}$ There is therefore

${ }^{100}$ Raz, n 10 above, 382.

${ }^{101}$ S. C. Craig, M. D. Martinez and J. G. Kane, 'Ambivalence and Response Instability: A Panel Study' in S. C. Craig and M. D. Martinez (eds), Ambivalence and the Structure of Political Opinion (New York: Palgrave Macmillan, 2005) 55, 56; M. Connor and C. Armitage, 'Attitudinal Ambivalence' in W. D. Crano and R. Prislin, Attitudes and Attitude Change (New York: Psychology Press, 2008) 268.

102 '[W]ith respect to that object [that he comes closest to wanting], he is drawn not only towards it but away from it too' Frankfurt, n 22 above, 165.

${ }^{103}$ Frankfurt, ibid, 159-176.

${ }^{104}$ See Christman, n 25 above, 185-186; Kymlicka, n 67 above, 81-82, 91; Ahdar and Leigh, n 5 above, 58.

This article is protected by copyright. All rights reserved. 
little potential for autonomy gain from the protection of resistant religious beliefs. As one scholar put it,

[individual autonomy] requires ... that people are capable of exposing each of their beliefs ... to appropriate tests, especially in the event of problems arising, and that whether or not they maintain such a commitment depends on how it fares in the tests ... People are autonomous in virtue of what can be - in virtue of what they can do in checking their beliefs ... ${ }^{105}$

If we return to the metaphor of an autonomous person as the 'helmsman' ${ }^{\text {, }}$ "w who steers her own course, to the extent that our beliefs are resistant, we are bound to "chart a course which could [not] have been otherwise. ${ }^{, 107} \mathrm{We}$ are less the authors of our own lives to the extent that we are shackled to our beliefs. As one of the studies about the resistance of religious beliefs concluded: holding such beliefs means that '[o]ne is less free to modify one's position, to take account of new, discrepant information'. ${ }^{108}$ All things being equal, then, holding a resistant belief (as compared to a non-resistant one) diminishes autonomy, by standing in the way of self-authorship with respect to that belief. Protecting such a belief will do little, if anything, to enhance autonomy. Autonomy is therefore an inapt basis for its protection.

These three arguments aimed to show that autonomy generally does not favour the protection of resistant religious beliefs. Are there any circumstances under which it does? It is possible that some hold resistant beliefs, which they identify with all their lives, and never hold competing dissonant beliefs. Despite the ubiquity of change in the human life, this is possible, if unusual. But even in such a case, the protection of the resistant religious belief would yield a limited autonomy gain since the resistance of the belief leaves little room for self-authorship with respect to it. Consider then another possibility: there may be circumstances under which people like Sal revise, or overcome the pull of, their resistant religious belief and act on beliefs or desires with which they identify. While these circumstances are theoretically possible, this paper has argued that they are psychologically

\footnotetext{
${ }^{105}$ P. Pettit, Republicanism: A Theory of Freedom and Government (Oxford: Clarendon Press, 1999) 186 (emphasis added)

106 T. May, 'The Concept of Autonomy' (1994) 31 American Philosophical Quarterly 133, 139-142; Raz, n 10 above, 384 .

${ }^{107}$ Raz, ibid, 382.

${ }^{108}$ Batson, n 77 above, 184 (emphasis added).
}

This article is protected by copyright. All rights reserved. 
unlikely, and therefore, rare. Consider yet another circumstance: if a person could, and did, choose to make their belief resistant, it is arguable that protecting that religious belief would enhance their autonomy. Choosing to hold a resistant belief would then be akin to other choices - like contracting or marrying - where people bind their future selves. But (even putting aside the weighty counterargument that autonomy requires us to always retain the freedom to change our mind ${ }^{109}$ ) there is nothing in the literature relating to resistant beliefs that suggests either that those who possess them have chosen to make them resistant, ${ }^{110}$ or that people have the ability to make their beliefs resistant at will. While theoretically possible, this scenario is not practically achievable. Overall, while there are circumstances under which protecting a resistant belief would enhance autonomy, these circumstances are unusual or psychologically unlikely.

To summarise, this section made three arguments for why autonomy generally does not favour the protection of resistant religious beliefs. First, resistant religious beliefs often hinder autonomy by hindering people (like Sal and Mal) from acting on beliefs or desires with which they identify. Protecting such resistant religious beliefs from state interference will not enhance their autonomy. Second, in cases like Cal's, those who hold resistant beliefs act ambivalently as a result of those beliefs. Since protecting such ambivalence-inducing resistant religious beliefs will not enhance autonomy, autonomy does not count in favour of their protection. Finally, the resistance of a belief impedes self-authorship with respect to that belief. Since protecting such a belief will do little, if anything, to enhance autonomy, autonomy is an unsuitable basis for its protection. Taken together, these three arguments show that the protection of resistant religious beliefs from state interference generally does not enhance autonomy, and that autonomy, therefore, does not favour their protection.

Since religious freedom jurisprudence does not currently make a distinction between resistant and non-resistant beliefs, protecting both equally, the autonomy rationale does not support the breadth of the protection offered by current religious freedom jurisprudence. ${ }^{111}$ More generally, the prevalence of resistant religious beliefs which are obstacles to autonomy

\footnotetext{
109 J. Radden, 'Second Thoughts: Revoking Decisions Over One's Own Future' (1994) 54 Philosophy and Phenomenological Research 787, 789.

${ }^{110}$ Rather, many such beliefs are associated with childhood socialisation, see text to $\mathrm{n} 82$ above.

${ }^{111}$ See, generally, Christman, n 25 above, 201-204.
}

This article is protected by copyright. All rights reserved. 
unsettles the growing consensus around the appropriateness of autonomy as the rationale for religious freedom.

The resistance of religious beliefs also raises questions about whether autonomy can support the current protection offered to proselytism. Since holding a resistant belief diminishes autonomy, autonomy may count against the protection of proselytism where the resulting beliefs are resistant to revision by the proselytisee. It is often suggested that beliefs acquired in childhood are likely to be resistant. ${ }^{112}$ There is also evidence that beliefs that are the product of 'manipulative proselytism' are resistant. ${ }^{113}$ Thus the prevalence of resistant religious beliefs raises important questions about whether the autonomy-based rationale supports the current protection offered to proselytism, and to parents who wish to give their children a religious upbringing. These questions are the focus of the section below.

\section{MANIPULATIVE PROSELYTISM}

In liberal jurisdictions, the right to religious freedom generally includes the freedom to proselytise. ${ }^{114}$ But not all forms of proselytism are protected. Proselytism which is coercive for instance, because it involves threatening people with imprisonment, death, or other such consequences - is generally regarded as antithetical to religious freedom. ${ }^{115}$ There have also been concerns about proselytism that might be characterised as 'manipulative'. New religious movements often come under scrutiny because of these concerns. It is claimed that these movements appeal to, or seek out, those who are vulnerable, alienated and psychologically unhealthy ${ }^{116}$ and that their methods of recruitment are deceptive. ${ }^{117}$ They are accused of 'brainwashing', a term used by way of analogy with the Chinese Communist programme of

\footnotetext{
${ }^{112}$ See references in $n 69$ above.

${ }^{113}$ R. S. Baron, 'Arousal, Capacity, and Intense Indoctrination' (2000) 4 Personality and Social Psychology Review 238.

${ }^{114}$ Eg, ECHR, Art 9; International Covenant on Civil and Political Rights, Art 18; Charter of Fundamental Rights of the European Union, Art 10; Bill of Rights Act 1990 (NZ), s 15.

${ }^{115}$ R. Ahdar, 'Regulating Religious Coercion' (2012) 8 Stanford Journal of Civil Rights and Civil Liberties 215, 216.

${ }^{116}$ J. Saliba, 'Teaching New Religious Movements: Views from the Humanities and the Social Sciences' in D. Bromley (ed), Teaching New Religious Movements (Oxford: OUP, 2007).

${ }^{117}$ ibid.
}

This article is protected by copyright. All rights reserved. 
'thought reform' used on prisoners of the Korean War. ${ }^{118}$ It is thought that those subjected to brainwashing must be 'deprogrammed' to remove its effects. ${ }^{119}$ Much of the rhetoric around the recruitment methods of new religious movements is alarmist. ${ }^{120}$ The "image of "brainwashing" as an all-powerful, irresistible and unfathomable, and magical method of achieving total control over the human mind"121 is highly implausible. Much of the 'cultic brainwashing' theory is now treated as 'pseudoscientific propaganda' by the social scientific community that studies new religious movements. ${ }^{122}$

That said, there are reasons to be concerned about the implications of manipulative methods of proselytism for the autonomy of the proselytisee. This section argues that some legally protected manipulative methods of proselytism do harm autonomy. The legal protection currently offered to these methods cannot therefore be supported by the autonomy rationale. As a first step, this section will outline a placeholder (rather than complete) account of the type of manipulative proselytism that cannot be supported by the autonomy rationale.

According to many prominent accounts of manipulation, a person is manipulated when they are influenced in such a way that their 'capacities for control over their mental lives ${ }^{123}$ are 'bypassed'. ${ }^{124}$ The language of 'bypassing' calls to mind futuristic cases where

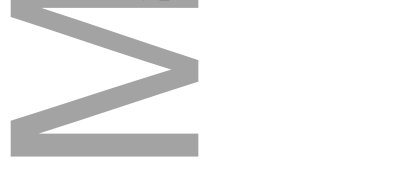

\footnotetext{
${ }^{118}$ See, generally, R. J. Lifton, Thought Reform and the Psychology of Totalism: A Study of 'Brainwashing' in China (Chapel Hill: University of North Carolina Press, 1989).

119 See D. Bromley and J. Richardson, The Brainwashing/Deprogramming Controversy: Sociological, Psychological, Legal, and Historical Perspectives (New York: Edwin Mellen Press, 1983).

${ }^{120}$ ibid.

${ }^{121}$ Lifton, $\mathrm{n} 118$ above, 4.

122 D. Anthony and T. Robbins, 'Pseudoscience Versus Minority Religions: An Evaluation of the Brainwashing Theories of Jean-Marie Abgrall' in J. Richardson (ed), Regulating Religion: Case Studies From Around the Globe (New York: Kluwer, 2004) 128.

${ }^{123}$ Mele, n 14 above, 166.

124 ibid, 164; T. Kapitan, 'Autonomy and Manipulated Freedom' (2000) 14 Philosophical Perspectives 81, 87; M. Hand, 'Religious Upbringing Reconsidered' (2002) 36 Journal of Philosophy of Education 545; D. Blumenfeld, 'Freedom and Mind Control' (1988) 25 American Philosophical Quarterly 215, 221; C. Coons and M. Weber, 'Investigating the Core Concept and Its Moral Status' in C. Coons and M. Weber (eds), Manipulation: Theory and Practice (Oxford: OUP, 2014) 11; M. Gorin, 'Towards a Theory of Interpersonal Manipulation' in Coons and Weber (eds), ibid, 88.
}

This article is protected by copyright. All rights reserved. 
people are controlled by devices that send commands directly to their brain. ${ }^{125}$ But we want to know how manipulative proselytism works in less futuristic cases. This is far from easy. ${ }^{126}$

Recent psychological studies of 'intense indoctrination' used in some religious movements take us beyond the rhetoric of 'brainwashing' to offer useful illustrations of manipulative methods of proselytism. These methods unfold in stages: creating interest in potential recruits; temporarily separating them from their usual social context; creating an environment of confusion, excitement, tiredness and disorientation; encouraging them to 'try out' group behaviour through social pressure or appeals to curiosity, politeness or authority. ${ }^{127}$ When successful, these methods eventually culminate in recruitment. Other features of these stages include
physical stress (especially sleep loss and altered diet), fear or guilt manipulations, regimented daily activity schedules, alteration in appearance (clothing, posture, hairstyle), and carefully orchestrated social pressure ... public self-criticism or confession, repetitive mental activity (e.g., meditation, memorizing doctrine), the presence of strong authority figures, a "messianic" group purpose (from which group members can derive a sense of importance), stereotypical depiction of nonmembers as evil or misguided, escalation of commitment in which the recruit is asked to engage in increasingly costly behaviour over time, and censorship of information. ${ }^{128}$

These techniques, the psychological literature suggests, produce internal states which impair attentional capacity and lower 'ability and motivation to carefully process social information. ${ }^{129}$ Proselytism using these, or similar, techniques can amount to the 'bypassing' of a person's 'capacities for control over their mental lives'. It is worth noting that this type of manipulative proselytism (to which the rest of this discussion is restricted) does not embrace many commonplace non-argumentative ways of influencing people including guilttripping, nagging or flirting.

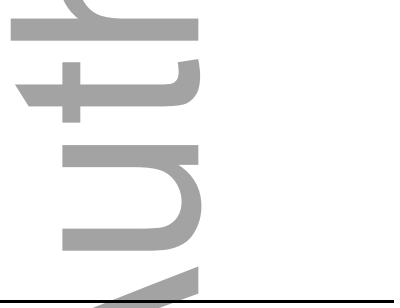

\footnotetext{
125 D. Blumenfeld, 'Freedom and Mind Control' (1988) 25 American Philosophical Quarterly 215, 216.

${ }^{126}$ See G. Dworkin, The Theory and Practice of Autonomy (New York: CUP, 1988) 18.

${ }^{127}$ Baron, n 113 above, 240-241.

128 ibid, 241.

${ }^{129}$ ibid, 252.
}

This article is protected by copyright. All rights reserved. 
It is widely assumed that manipulation diminishes autonomy. ${ }^{130}$ If you are manipulated, the thoughts, aims, desires that result from the manipulation are not yours, but your manipulators'. You are 'a puppet on a string' or 'putty in another's hands. ${ }^{131}$ Having your life shaped by someone else is clearly inconsistent with autonomy, the ideal of shaping your own life. Moreover, manipulative proselytism appears to result in resistant religious beliefs, ${ }^{132}$ as the previous section argued, this has serious consequences for autonomy. Manipulative proselytism therefore generally diminishes the autonomy of the proselytisee. (The claim here is that manipulative proselytism diminishes autonomy only 'generally', rather than in every case, to make exception for potential unusual cases where someone, fully understanding the implications of using manipulative techniques of proselytism, orchestrates their use on herself, for instance in order to overcome an addiction or increase self-control.)

Barring such exceptional cases, autonomy does not count in favour of the protection of religious proselytism that amounts to manipulation. This is so because of the effects of manipulative proselytism on the autonomy of the proselytisee. But one might object that we ought to take into account the autonomy of the proselytiser as well. The freedom to proselytise enhances the autonomy of the proselytiser. ${ }^{133}$ Is the proselytiser's interest sufficient to support the protection of manipulative proselytism on autonomy grounds? No; as indicated earlier, autonomy does not require that we have every option open to us. Nor are all options of equal importance for autonomy. The denial of the option of eating a particular flavour of ice cream diminishes autonomy much less (if at all) than the denial of the option of practicing the religion of our choice. Generally, losing the freedom to engage in manipulative proselytism, while retaining the freedom to engage in the many modes of non-manipulative proselytism available, diminishes the proselytiser's autonomy only to a small degree. On the

${ }^{130}$ Koppelman, n 5 above, 293; Evans, n 5 above 29; Raz, n 10 above; J. S. Taylor, Practical Autonomy and Bioethics (Hoboken: Taylor and Francis, 2010) 7-8.

${ }^{131}$ C. Coons and M. Weber, 'Investigating the Core Concept and Its Moral Status' in Coons and Weber (eds), n 124 above, 8 .

${ }^{132}$ Baron, n 113 above, 242-243.

${ }^{133}$ P. M. Taylor, 'The Questionable Grounds of Objections to Proselytism and Certain Other Forms of Religious Expression' [2006] Brigham Young University Law Review 811; T. Stahnke, 'Proselytism and the Freedom to Change Religion in International Human Rights Law' [1999] Brigham Young University Law Review 251; P. G. Danchin, 'Of Prophets and Proselytes: Freedom of Religion and the Conflict of Rights in International Law' (2008) 49 Harvard Journal of International Law 249, 256, 268.

This article is protected by copyright. All rights reserved. 
other hand, if the proselytisee is manipulated into having religious beliefs, a crucial area of her life is shaped not by her, but by her manipulator. Not only this, the religious beliefs she is manipulated into having, are likely to be resistant to revision. ${ }^{134}$ Manipulative proselytism is likely therefore to harm the autonomy of the proselytisee to a very high degree. Therefore, despite the proselytiser's autonomy interests, autonomy cannot serve as the rationale for the protection of manipulative proselytism.

What is the upshot of this for the protection currently offered to religious beliefs and practices under the ECHR? Article 9 is taken to protect against manipulative proselytism by the state. ${ }^{135}$ The ECtHR has also voiced concern about certain kinds of proselytism by nonstate actors. In Kokkinakis for instance, the Court held that Article 9 does not protect 'improper proselytism' as opposed to 'Christian witness' and 'true evangelism'. ${ }^{136}$ But beyond the fact that the applicant's actions in the case - calling at the house of the wife of an Orthodox cantor and engaging in a discussion with her - did not amount to improper proselytism' the Court explicitly chose not to define 'improper proselytism' ${ }^{137}$ It therefore does not offer guidance on the protection extended to manipulative proselytism. ${ }^{138}$ Leela Forderkreis v Germany ${ }^{139}$ also involved a State response to allegations of manipulative proselytism by a new religious movement. But these allegations were unverified, and a domestic court prohibited the state from making this allegation in its information campaign. So the case does not shed much light on the nature or legal status of manipulative proselytism.

The Court's reluctance to address the status of manipulative proselytism is strong. The facts of another ECHR case, Riera Blume v Spain, ${ }^{140}$ offered an ideal opportunity for the ECtHR to provide clarity about manipulative proselytism. ${ }^{141}$ Here adult members of a so-

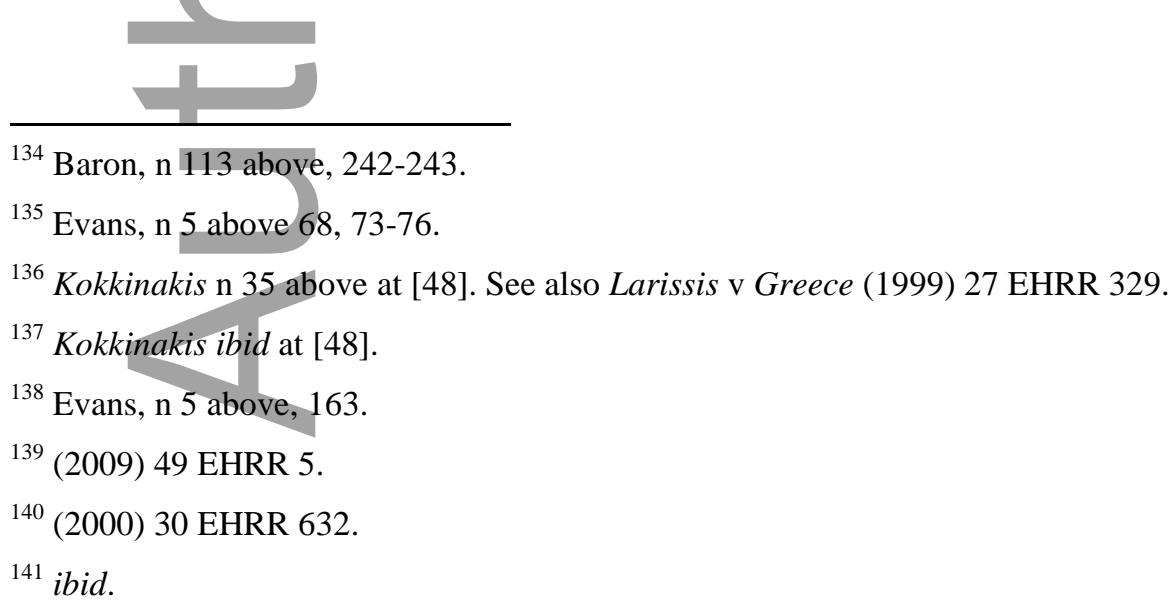


called sect were detained by family members, with the co-operation of police, in order to be 'deprogrammed'. The families of the applicants complained that the 'sect'

managed to bring about a complete change of personalities in their followers, leading them to break off ties with their family and friends and inciting them to prostitution and other activities designed to obtain money for the organisation. ${ }^{142}$

Despite the salience of the issues raised for religious freedom, the Court refused to examine the case under Article 9, restricting itself to finding that there had been a violation of Article 5 of the ECHR (which protects the right to liberty and security). ${ }^{143}$ There is reason to believe that the Court's reluctance to address the status of manipulative proselytism might stem from the difficulty of identifying manipulative proselytism. As one judge in Kokkinakis pointed out: '... it is evidently difficult to establish where spiritual means of conversion cross the borderline between insistent and intensive teaching, which should be allowed, and spiritual coercion akin to manipulation'. ${ }^{144}$

Against the context of the Court's reluctance to address the status of manipulative proselytism, its recent decision on manipulative proselytism of children is significant. Vojnity v Hungary, involved a father who domestic authorities and courts had described as engaging in 'heavy-handed proselytism, 145 directed to his son and 'forc[ing] his beliefs on his son' ${ }^{\text {, }}$ " to the point of endangering his development. ${ }^{147}$ The ECtHR stressed that parents have the right to proselytise to their children 'even in an insistent or overbearing manner ${ }^{148}$ It therefore concluded that 'protecting the child's psychological health from the purported stress exerted by the [father's] intensive efforts to transfer his [religious] convictions to him' did not 'qualify as a ... weighty reason' sufficient to justify the differential (and less favourable) access rights accorded to the father. ${ }^{149}$ In reaching this conclusion, the court drew support

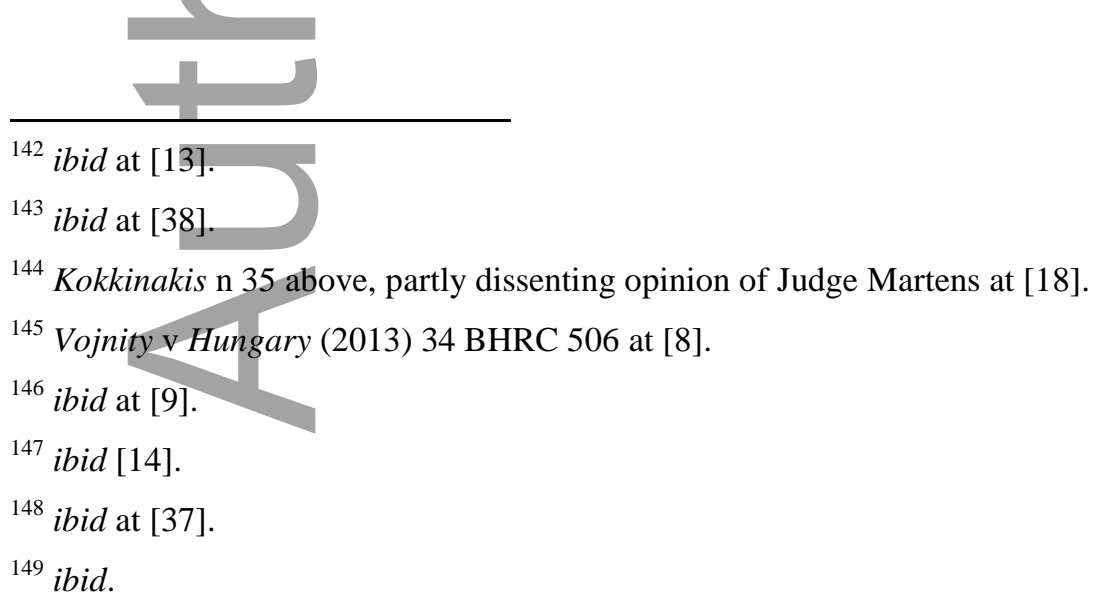

This article is protected by copyright. All rights reserved. 
from previous ECHR cases on children's religious upbringing, as well as from Article 2 of Protocol 1 to the ECHR, which reads:

In the exercise of any functions which it assumes in relation to education and to teaching, the State shall respect the right of parents to ensure such education and teaching in conformity with their own religions and philosophical convictions' (emphasis added).

Thus it now seems clear that ECHR jurisprudence protects parents' right to subject their children to proselytism, without drawing the line even at manipulative proselytism. ${ }^{150}$

The Court's approach towards the manipulative proselytism of children by parents is supported by other decided cases involving Article 2 of Protocol 1, where the court is at pains to emphasise 'the right of parents to enlighten and advise their children, to exercise with regard to their children natural parental functions as educators, or to guide their children on a path in line with the parents' own religious or philosophical convictions. ${ }^{151}$ Lady Hale in Williamson (with whom the other four judges agreed) saw in Articles 8 and 9 and Article 2 of Protocol 1 the principle that 'it is important in a free society that parents should be allowed a large measure of autonomy in the way in which they discharge their parental responsibilities.' 152 These statements of recognition of parents' rights to give children a religious upbringing were not qualified to exclude manipulative proselytism. Thus it appears that ECHR jurisprudence protects parental rights to give their children a religious upbringing even when this diminishes the autonomy of children. It has been argued, based on a short admissibility judgement in the Çiftçi v Turkey case, ${ }^{153}$ that the ECtHR's approach has

shifted from respecting parental convictions in education to protecting the child against indoctrination, including that undertaken by parents and private religious education classes. ${ }^{154}$

However, the Çiftçi case concerned access to religious classes provided by the state ${ }^{155}$ for which completion of primary school was essential. The case does not appear to countenance

${ }^{150}$ R. Taylor, 'Parental Responsibility and Religion' in R. Probert, S. Gilmore and J. Herring (eds), Responsible Parents and Parental Responsibility (Oxford: Hart Publishing, 2009).

${ }^{151}$ Kjeldsen, Busk Madsen and Pedersen (1976) 1 EHRR 711 at [54].

${ }^{152} R$ (Williamson) v Secretary of State for Education and Employment $\mathrm{n} 46$ above at [72].

${ }^{153}$ Çiftçi v Turkey ECtHR 17 June 2004.

${ }^{154}$ S. Langlaude, The Right of the Child to Religious Freedom in International Law (Boston: Martinus Nijhoff, 2007) 214. 
interference with parents' right to educate their children privately in religion. ${ }^{156}$ It does not therefore represent a shift in ECHR jurisprudence away from protecting parents' right to subject their children to proselytism, even when manipulative.

Before we can conclude that ECHR jurisprudence on parental religious rights is unsupported by the autonomy rationale here, we must face a set of related objections. The first is that it is misconceived to talk of the autonomy of children being diminished as children do not yet have the capacity for autonomy. The second is that parents have a particularly strong autonomy interest in giving their children a religious upbringing. These objections may suggest that valuing autonomy commits us to protecting parental freedom to engage in manipulative proselytism of their children.

Many children are, to a degree, deficient in the capacities required for autonomy, including reasoning and self-control. ${ }^{157}$ Many children are also lacking in appreciation for the long-term consequences of their actions, as well as information and experience of the world. ${ }^{158}$ But we cannot conclude that they have no capacity for autonomy. Even very young children have been shown to have autonomy, in a local sense, with respect to certain decisions and activities. ${ }^{159}$ When it comes to older children, say between the ages of 15 and 18, their capacities for autonomy may well be as developed as those of an adult. It is therefore not misconceived to talk of the autonomy of children, just because their capacity for autonomy may be partial and developing. This capacity for autonomy, such as it is, must be respected and nurtured. To subject them to manipulative proselytism is to treat them like programmable dolls, owned by their parents, rather than partially autonomous beings.

\footnotetext{
${ }^{155}$ For a translation of Law no 633 which the case related to, see Ö. H. Çınar, 'Compulsory Religious Education in Turkey' (2013) 8 Religion and Human Rights 223, 228-229.

${ }^{156}$ See N. Oktem, 'Religion in Turkey' [2002] Brigham Young University Law Review 371, 397: 'There is no restriction on private religious instruction outside of school hours'.

${ }^{157}$ H. LaFollette, 'Circumscribed Autonomy: Children, Care, and Custody' in U. Narayan and J. Bartkowiack (eds), Having and Raising Children: Unconventional Families, Hard Choices, and the Social Good (University Park, PA: Penn State University Press, 1999) 142.

158 ibid.

${ }^{159}$ A. Mullin, 'Children, Paternalism and the Development of Autonomy' (2014) 17 Ethical Theory and Moral Practice 413, 421.
}

This article is protected by copyright. All rights reserved. 
Putting aside the degree to which children are autonomous, they have an interest in becoming autonomous, including in the religious domain. Autonomy is not achieved suddenly on the eve of a child's $18^{\text {th }}$ birthday. Children develop capacities required for autonomy with practice over time. ${ }^{160}$ An upbringing which includes extensive manipulative proselytism affords children little opportunity to develop the capacities for autonomy in the religious domain. As Mill argued, these capacities 'are called into no exercise by doing a thing merely because others do it, no more than by believing a thing only because others believe it. ${ }^{161}$ The methods associated with manipulative proselytism are also likely to diminish self-confidence to the point that it undermines the development of a child's autonomy. ${ }^{162}$ Finally, recall that manipulative proselytism tends to result in resistant religious beliefs. ${ }^{163}$ So a child who is subject to manipulative proselytism will find it particularly difficult to revise these beliefs later in life. The resulting consequences for autonomy have already been discussed.

Turning to the second objection, while parents may have an autonomy interest in giving their children a religious upbringing, it is important to bear in mind that there are many ways of giving children a religious upbringing - including teaching, reasoning, leading by example, introduction into faith communities - that would not amount to manipulative proselytism. Nor, on this paper's understanding, would familiar non-argumentative forms of parental influence such as nagging, wheedling, guilt-tripping, punishing, rewarding or offering incentives and disincentives amount to manipulative proselytism. Thus the loss of manipulative proselytism as an option for parents, who have so many other methods of proselytism open to them, would only marginally diminish their autonomy. On the other hand, manipulative proselytism diminishes and subverts the partial and developing autonomy of children to a very high degree. Therefore, the autonomy rationale cannot support the protection of manipulative proselytism by parents to their children.

So ECHR jurisprudence protects religious proselytism - including manipulative proselytism of children by parents, and possibly manipulative proselytism more generally -

\footnotetext{
${ }^{160}$ LaFollette, $\mathrm{n} 157$ above, 148.

${ }^{161}$ S. Collini (ed), J. S. Mill - On Liberty and Other Writings (Cambridge and New York: CUP, 1989) 59; see LaFollette, ibid, 148.

${ }^{162}$ Mullin, n 159 above, 413, 424.

${ }^{163}$ Baron, n 113 above, 242-243.
}

This article is protected by copyright. All rights reserved. 
that cannot be supported by the autonomy rationale. To be clear, this is not to say that the current legal position is not justified; there may well be good reasons to give parents broad rights over their children's upbringing. The more limited conclusion here is that the autonomy rationale does not support the breadth of the protection offered by current religious freedom jurisprudence.

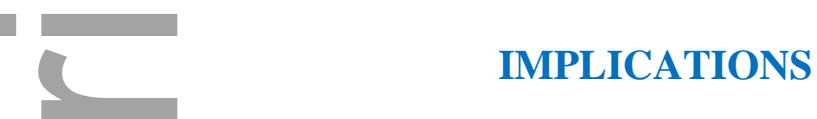

This paper finds that that the autonomy rationale for religious freedom does not support the protection currently offered to religious beliefs, practices and proselytism by the right to religious freedom. To parse out the implications of this finding, it is important to appreciate the distinctive ways in which the protection of different religious beliefs, practices and proselytism affect autonomy.

The autonomy rationale cannot support the range of protection currently offered to resistant religious beliefs, and practices based on these beliefs. This paper argues that there is no autonomy-based reason to protect many such beliefs and practices. However, there is no autonomy-based reason not to protect them either. Withdrawing protection of resistant beliefs and practices, in cases like those of Sal, would not enhance her autonomy; her resistant beliefs would remain an obstacle to her autonomy regardless of whether they are protected or not. So while the autonomy rationale does not support the protection of such beliefs and practices, the legal right to religious freedom can coherently protect such beliefs and practices by appealing to other rationales to supplement autonomy.

The autonomy rationale also does not support the protection currently offered to some manipulative proselytism. This is because such proselytism diminishes the autonomy of the proselytisee. There is in fact an autonomy-based reason not to protect such autonomydiminishing proselytism. This contrasts with the discussion above on the protection of resistant beliefs. If autonomy-diminishing proselytism were not protected, the state and other actors would be better placed to prevent it, preserving the autonomy of the proselytisee. If we value autonomy, interference with such proselytism would be welcome. If we take autonomy to be at least $a$ rationale underpinning the legal right to religious freedom, this right cannot coherently protect autonomy-diminishing proselytism to the extent that it currently does in ECHR jurisprudence. Nor can the right coherently protect such proselytism by appealing to 
other rationales to supplement autonomy. For if any supplemental rationale weighs in favour of protecting such proselytism, autonomy still weighs against it.

Thus, in order to coherently retain autonomy as a rationale for religious freedom: first, autonomy must be supplemented with other rationales for the protection of resistant beliefs, and second, the jurisprudence on manipulative proselytism must change. There is reason to retain autonomy as a rationale, given its prominence in legal doctrine, and given that it does justify some facets of the jurisprudence on religious freedom. ${ }^{164}$ So the potential for the fulfillment of each of these two conditions will be briefly explored in turn.

While it would be impossible to fully evaluate the potential for other rationales to supplement autonomy here, there are some promising candidates. There is a long tradition of justifying religious freedom by reference to conscience. While not without its limitations, ${ }^{165}$ the idea that religious freedom is necessary to protect conscience, understood as the faculty with which people discern moral duties ${ }^{166}$ or the meaning of life, ${ }^{167}$ is certainly an attractive one. This idea is often coupled with an understanding of persons as 'encumbered selves, claimed by duties they cannot renounce', ${ }^{168}$ and of religious beliefs and practices as 'deeply constitutive aspects of people's identity' ${ }^{169}$ Asking people to change or refrain from acting on their religious beliefs is then asking them to 'betray ... their legitimate sense of who they are'. ${ }^{170}$ This rationale may well justify the protection of religious beliefs and practices, including resistant beliefs, even where autonomy does not.

Another rationale, offered by Ronald Dworkin, is that the state should not interfere with religious belief or practice because this would breach the principle of authenticity. ${ }^{171}$ Authenticity demands that noone else make decisions about our religious beliefs and

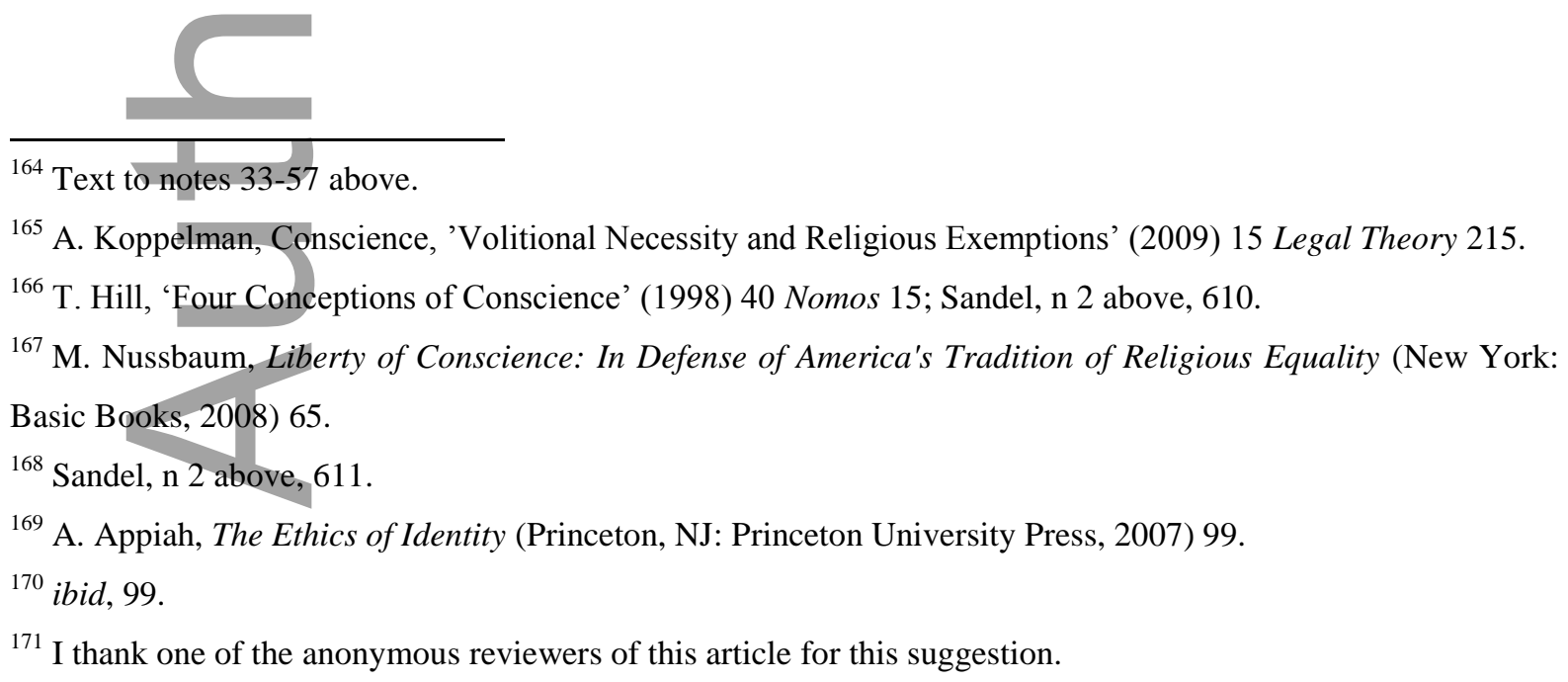


practices, and more broadly about 'the best use to which a person's life should be put ...'172 This rationale for religious freedom, Dworkin emphasises, does not boil down to autonomy. For authenticity is compromised by the fact of state interference, not its effects on autonomy: 'in usurpation, not limitation'. ${ }^{173}$ This rationale has potential to justify the protection of resistant beliefs because it shifts focus from the autonomy of individuals to the legitimacy of state interference.

Conscience and authenticity are not the only potential supplementary rationales, or even necessarily the most promising. Much more could be said about the other powerful rationales mentioned earlier in this paper including the value of faith, ${ }^{174}$ the futility of religious coercion, the importance of finding religious truth ${ }^{175}$ and the value of preventing religious conflict. ${ }^{176}$ No attempt is made here to identify the most appropriate supplementary rationales for religious freedom. Rather, this discussion merely indicates that rationales exist which can supplement, and compensate for, the justificatory deficiencies of the autonomy rationale.

The second condition for autonomy to continue as part of the rationale for the legal right to religious freedom was the development of ECHR jurisprudence on manipulative proselytism. Commentators have in the past appealed to the autonomy rationale to call for the development of the jurisprudence to extend the protection offered to religious beliefs and practices. ${ }^{177}$ This paper calls for the jurisprudence to develop to restrain the protection of religious beliefs and practices, in order to promote autonomy. For example, the text of Article 9(2), which permits certain limitations on religious freedom including to protect the rights and freedoms of others, could be used to preclude the protection of manipulative proselytism. The distinctions drawn by the court in the (admittedly problematic) ${ }^{178}$ Kokkinakkis case between proper and improper proselytism could be developed to track the distinction between autonomy-neutral and autonomy-diminishing proselytism. The suggestion in Vojnity $\mathrm{v}$

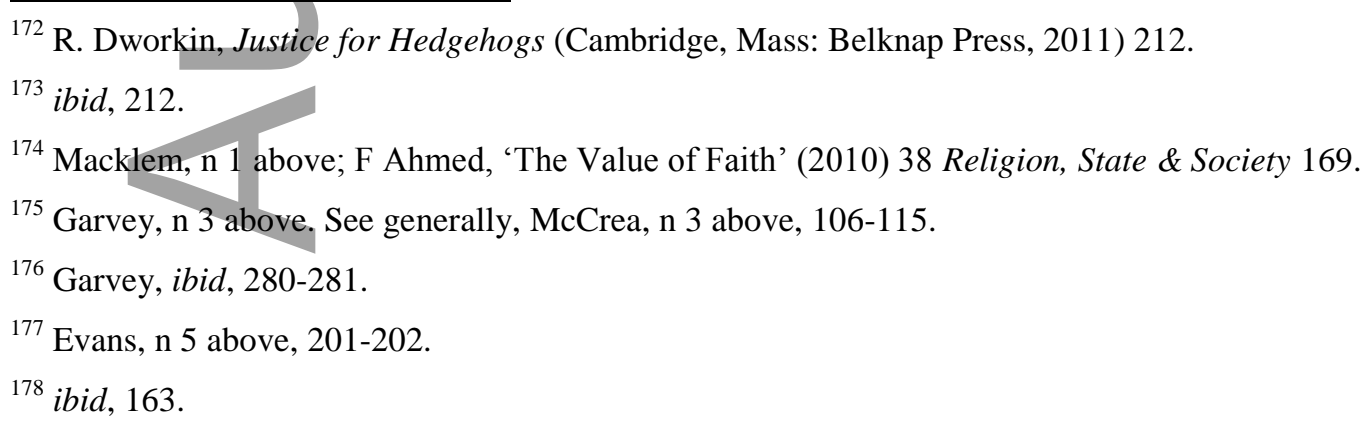


Hungary that parents do not have the right to proselytise to their children in a way that exposes them to 'psychological harm' might serve to restrict parents' rights on the basis that manipulative proselytism amounts to 'psychological harm'. ${ }^{179}$ (To be clear, however, the ECtHR in that case did not appear to consider manipulative proselytism 'psychological harm', so this would require a change in the ECHR jurisprudence). If these two conditions are met, the findings in this paper leave the door open for a justificatory role for autonomy, as part of a composite rationale for religious freedom.

\section{SIGNIFICANCE AND CONCLUSION}

This paper's finding that autonomy does not favour the current protections offered to religious belief and practice in ECHR jurispudence implies that other rationales are needed to supplement autonomy, and that the current protection for manipulative proselytism must be curtailed. A number of other jurisdictions with protections for religious freedom also justify these protections by reference to autonomy. For example, Canadian courts have relied particularly heavily on autonomy as the justification for their religious freedom jurisprudence; ${ }^{180}$ religious freedom jurisprudence in the US is similarly dependent on the autonomy rationale. ${ }^{181}$ This paper's findings and implications are of significance for such jurisdictions as well.

The analysis in this paper also has significance beyond the autonomy rationale. Courts and commentators have made conflicting assumptions about the ease with which religious beliefs can be revised. ${ }^{182}$ The paper's demonstration of the resistant nature of some religious beliefs, drawing on psychological studies, enhances our understanding of religious beliefs. This enhanced understanding could help determine the correct legal response to claims for protection of such beliefs. Similarly, courts and commentators have thus far struggled to clearly identify what counts as manipulative proselytism in religious freedom cases. This might well be the reason why the ECtHR in Riera Blume v Spain, a case essentially about alleged manipulative proselytism, side-stepped the religious freedom issue altogether. The

\footnotetext{
${ }^{179}$ Vojnity v Hungary n 145 above at [37].

${ }^{180}$ Berger, $\mathrm{n} 5$ above 277, 291-300; Syndicat Northcrest v Amselem n 9 above at [40], [42]; $R$ v Big M Drug Mart Ltd [1985] 1 SCR 295, 351 (SCC); Zylberberg v Sudbury Board of Education n 9 above.

${ }^{181}$ On autonomy in US religious freedom jurisprudence, see Greenawalt, n 5 above, 3-4; Tribe, n 9 above, 1284 1300; Sandel, n 2 above, 607-609.

${ }^{182}$ See text to notes 64-75 above.
}

This article is protected by copyright. All rights reserved. 
placeholder account of manipulative proselytism offered by this paper could serve as a starting point for the development of an account which can help decide such cases.

Finally, while the arguments in this paper are focussed on religious freedom, they may be of further significance for other legally-protected freedoms. As indicated earlier, resistant religious beliefs are not necessarily unique in their resistance to revision. ${ }^{183}$ If other beliefs - eg, political beliefs - are also resistant, this may have implications for whether autonomy supports the protection of those beliefs as well. Similarly, the manipulative methods of proselytism discussed in this paper are by no means necessarily restricted to (religious) proselytism. After all, in the past, similar methods were associated with Communist 'thought reform' and 'brainwashing'. ${ }^{184}$ If (non-religious) manipulative methods of influencing others are likely to raise similar concerns to those raised by manipulative (religious) proselytism, autonomy may not support the protection of these forms of influence either. This is consistent with scholarly suggestions that autonomy does not, in principle, support the protection of manipulative speech, ${ }^{185}$ even though it is commonly taken to be a primary rationale for freedom of speech. ${ }^{186}$ There may be further arguments for whether many rights and freedoms which may appear to enhance autonomy - political freedom, the right to marry, the right to die, freedom of contract, for example - do, in fact, do so. The arguments in this paper may therefore prompt further scrutiny into the extent to which autonomy supports not just religious freedom, but other liberal freedoms as well.

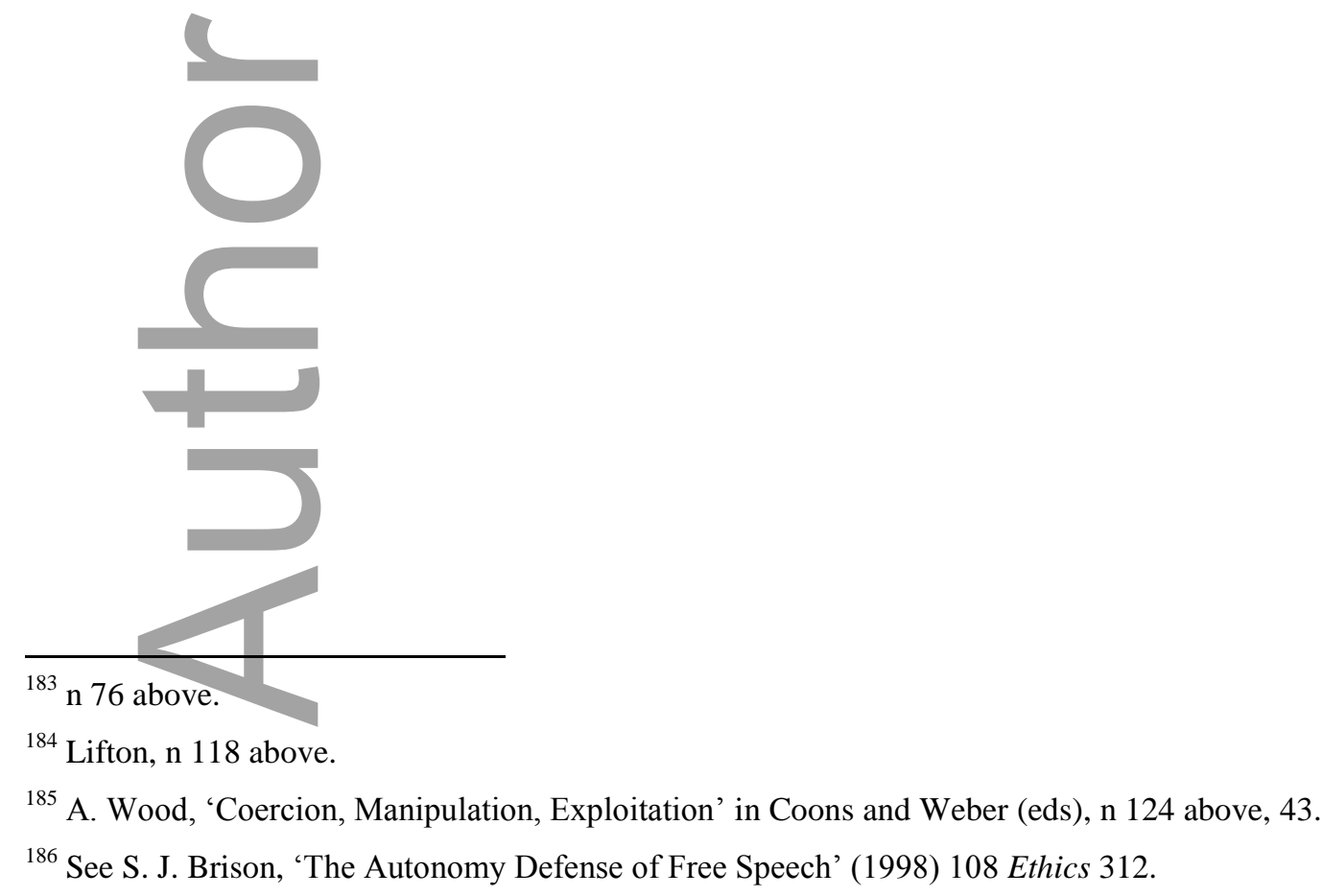

This article is protected by copyright. All rights reserved. 


\section{University Library}

\section{- M M I N E R VA A gateway to Melbourne's research publications}

Minerva Access is the Institutional Repository of The University of Melbourne

Author/s:

Ahmed, F

Title:

The Autonomy Rationale for Religious Freedom

Date:

2017-03-01

Citation:

Ahmed, F. (2017). The Autonomy Rationale for Religious Freedom. MODERN LAW REVIEW, 80 (2), pp.238-262. https://doi.org/10.1111/1468-2230.12253.

Persistent Link:

http://hdl.handle.net/11343/292592 